brazilianpoliticalsciencereview

ART I CLE

\title{
State Transfers, Taxes and Income Inequality in Brazil ${ }^{*}$
}

\author{
Marcelo Medeiros
}

Universidade de Brasília, Brazil

\author{
Pedro H. G. F. Souza
}

Instituto de Pesquisa Econômica Aplicada, Brazil

Using a factor decomposition of the Gini coefficient, we measure the contribution to inequality of direct monetary income flows to and from the Brazilian State. The income flows from the State include public sector workers' earnings, Social Security pensions, unemployment benefits, and Social Assistance transfers. The income flows to the State comprise direct taxes and employees' social security contributions. Data come from the Brazilian POF 2008-09. We do not measure indirect contributions to inequality of subsidies granted to and taxation of companies, nor the in-kind provision of goods and services. The results indicate that the State contributes to a large share of family per capita income inequality. Incomes associated with work in the public sector-wages and pensions-are concentrated and regressive. Components related to the private sector are also concentrated, but progressive. Contrary to what has been found in European countries, public spending associated with work and social policies is concentrated in an elite group of workers and, taken as a whole, tends to increase income inequality. Redistributive mechanisms that could reverse this inequality, such as taxes and social assistance, are very progressive but proportionally small. Consequently, their effect is completely offset by the regressive income flows from the State.

Keywords: Income distribution; social inequality; social policies; public work; pensions.

(*) http://dx.doi.org/10.1590/1981-38212014000200009

For replication, see bpsr.org.br/files/arquivos/Dataset_Medeiros_Souza.html

The authors would like to thank Branko Milanovic and Rodolfo Hoffmann for their comments and suggestions on an early draft of this paper, as well as the journal's anonymous reviewers for their reading and critiques. 
$\mathrm{T}$ his study aims to measure the net contribution of direct flows of income to and from the State (wages, transfers, and taxes) to income inequality. Our focus is not only on public expenditures but also on the collection of resources by direct taxation. Specifically, we simultaneously consider all three major types of income flows between the State and families: taxes, transfers and payments to public sector workers. We limit our analysis to the direct monetary income flows between families and the State. This excludes the distributive impacts of three major types of State intervention: taxes, transfers to firms and the provision of public services. The former is an indirect income flow; whereas, the latter is a non-monetary transfer.

We are testing the hypothesis that the State plays a perverse distributional role in Brazil. The state contributes to a large share of income inequality, as it operates its wage and social and tax policies in a three-tiered fashion: on the first level, it supports an elite group of workers in the public sector earning high wages and with pensions; on the second level, it provides intermediate pension benefits and unemployment insurance only to formal workers in the private sector; and finally, on the third level, it gives little weight to redistributive measures such as taxes and basic income policies for the low income masses in the informal sector.

This hypothesis assumes that the regressive actions of the State are a typical result of path-dependency in politics. Since its inception, the Brazilian welfare state has followed a corporatist model that offers protection to workers in the more developed sectors of the labor market-including State workers-but excludes most of the general population from it. This arrangement further entrenched into power certain strongly organized groups, such as state bureaucrats and public servants, which exert considerable influence upon a large share of the State's social spending and wage policies.

Inequality is often associated with weak public institutions. We, however, offer a different argument. We maintain that powerful public and private institutions can, in fact, be worse than weak ones. If the quality of institutions is understood only as a combination of their stability, autonomy, and size, then we argue that it is not the quality of the institutions that matters most to inequality.

It is also common to link social policies to inequality reduction, particularly by stressing that larger welfare states tend to result in lower 
inequality. Our study does not endorse this view, as it is possible to have a large welfare state that, in fact, provides the bulk of its benefits to the upper middle classes, thereby increasing the level of inequality.

Previous comparative studies on developed countries, predominantly on countries of the Organization for Economic Cooperation and Development (OECD), have shown that the State reduces inequality. These studies found that public work contributes to reduced inequality (BLAU and KAHN, 1996; GUSTAFSSON and JOHANSSON, 1999; MILANOVIC, 1994), that strong unions and centralized bargaining of wages typical of public workers are determinants of lower levels of income inequality (CHECCHI and GARCÍA-PEÑALOSA, 2010; GOTTSCHALK and SMEEDING, 1997; GUSTAFSSON and JOHANSSON, 1999) and that corporatist welfare state policies are more capable of reducing inequality than targeted policies because of the "paradox of redistribution", that is, (contributory) universalism legitimizes more spending than targeting and it is the level of expenditures that matters most to inequality (GOUDSWAARD and CAMINADA, 2010; KORPI and PALME, 1998; MAHLER and JESUIT, 2006; SMEEDING, 2005). Other studies have identified that taxation, particularly direct taxation, tends to be progressive and the higher the taxation, the lower the level of inequality (ATKINSON, 2003; GOTTSCHALK and SMEEDING, 1997; GOUDSWAARD and CAMINADA, 2010).

While these conclusions depend on the methodology employed, particularly those related to how the contribution of social benefits is computed (FUEST, NIEHUES AND PEICHL, 2010; WANG, CAMINADA and GOUDSWAARD, 2012), they seem to hold true for all OECD countries. Our results, however, indicate that, except for that which refers to taxation, these conclusions cannot be generally applied to a developing country or, at the very least, to Brazil. A public sector with well-organized workers and a fairly large welfare state in terms of public expenditure do not automatically translate into less income inequality in the country.

By decomposing income inequality, we found that public work - especially the public-private wage gap - contributes to increased inequality, probably because the labor movement of public sector workers is stronger than its counterpart in the private sector. Corporatism does result in a high level of social 
spending, but this expenditure is very concentrated, resulting in the opposite of what happens with targeted assistance. Direct taxes are very progressive, although they represent a small share of total taxation in the country. The end result is that, in Brazil, the direct income flows to and from the State contributes to approximately one third of all inequality in disposable income. The advantages of public workers in wages and pensions alone contribute to around one tenth of this inequality.

To a large extent, our study converges with previous research regarding inequality in Brazil. In short, the existing studies show that i) direct taxation is very progressive and contributes to reduced inequality (AFONSO and FERNANDES, 2005; CASTRO, 2014; MEDEIROS and SOUZA, 2013; PINTOS-PAYERAS, 2008, 2010; RANGEL, 2011; ROCHA, 2002; SILVEIRA, 2008, 2010; SOARES et al., 2010); ii) social security pensions are regressive, especially due to the high concentration of benefits within the system that covers workers in the public sector-in the long run-and considering contributions, this regressiveness is reduced (AFONSO and FERNANDES, 2005; BARROS et al., 2007; FERREIRA, 2006; HOFFMANN, 2003a, 2003b, 2009; MEDEIROS and SOUZA, 2014; RANGEL, VAZ and FERREIRA, 2009; SILVEIRA, 2008, 2010); iii) social assistance benefits are very progressive, but contribute little to total inequality given their small share in total income (BARROS et al., 2007; HOFFMANN, 2009; MEDEIROS and SOUZA, 2013; ROCHA, 2008; SOARES et al., 2009); iv) wages paid to public servants have a very unequal distribution, are often higher than those paid in the private sector and tend to be regressive (BARBOSA and SOUZA, 2012; DARÉ, 2011; DARÉ and HOFFMANN, 2012; HOFFMANN, 2009; SOUZA and MEDEIROS, 2013; VAZ and HOFFMANN, 2007).

We do not take into account indirect income flows, in-kind services and non-monetary transfers, such as indirect taxes, public education and health spending, and subsidies to firms. For the purposes of this study, it is simply not possible to reliably estimate their effects on income inequality. Our focus is on direct monetary taxes and transfers, not on all possible ways the State can affect inequality. We believe the monetary income flows analyzed below are of interest by themselves for two reasons. First, the wages and transfers we analyzed cover a large share of all State expenditures: in 2006, combined together, wages and 
transfers accounted for over $21 \%$ of GDP, whereas the total tax revenue reached slightly over 34\% of GDP (MOSTAFA, SOUZA and VAZ, 2010; SANTOS, 2010). Second, it is not far-fetched to speculate that the net effect of omitting all indirect and non-monetary income flows is regressive. If some admittedly strong assumptions are to be believed, then the regressiveness of indirect taxes, interest payments and subsidized credit, among others, swamp the moderately egalitarian profile of education and health care expenditures (CARVALHO, SIQUEIRA and NOGUEIRA, 2013; HIGGINS and PEREIRA, 2013; IMMERVOLL et al., 2006; MOSTAFA, SOUZA and VAZ, 2010; PINTOS-PAYERAS, 2010; SILVEIRA, 2010).

Finally, we should add a remark regarding the quality of the data and of our estimates. The survey we use, the Brazilian Consumption and Expenditure Survey 2008-09 (Pesquisa de Orçamentos Familiares - POF), has the most reliable questionnaire regarding income data in Brazil. Yet, at least one study based on tax data (MEDEIROS, SOUZA and CASTRO, 2015b) shows that the total levels of inequality seem to be underestimated by all household surveys in the country. This, of course, may bias our estimates. In addition, we were not able to calculate proper confidence intervals for our estimates. We did calculate standard errors using bootstrap procedures assuming random sampling and found nothing that should compromise our results. Still, our results should be taken with caution.

\section{Methodology}

The microdata used in the study comes from the Brazilian Consumption and Expenditure Survey 2008-09 (Pesquisa de Orçamentos Familiares - POF), which was conducted between June 2008 and June 2009 by the Brazilian Institute of Geography and Statistics (IBGE), the country's central statistics office. The POF has national coverage and a total sample size of roughly 190 thousand people in 56 thousand households, which corresponds to a population of 189 million people in 57.5 million households.

The POF is primarily a consumption-oriented survey but it also collects extensive data on incomes. The 2008-2009 survey covers approximately 110 different income sources with a 12-month reference period, making the POF the most reliable survey regarding income data in Brazil. As a benchmark, it is worth mentioning that Pesquisa Nacional por Amostra de Domicílios (PNAD), a well- 
known household survey in Brazil, only collects incomes and earnings for approximately ten income sources with a thirty-day reference period. Reported income levels in the POF are usually higher than in other household surveys and are closer to the National Accounts estimates.

Our main variable of interest is the disposable household per capita income, which encompasses labor and capital incomes, public and private transfers, benefits net of direct taxes, and employees' Social Security contributions. Non-monetary incomes, such as in-kind payments, were discarded. A negligible number of households with negative disposable income were also excluded from our analysis.

Both income and tax data were deflated to January 2009 using a standard consumer price index. Absolute income levels are only of marginal interest to us, but the tables below provide information on them, presented in 2009 PPP Dollars (using the United Nations' Millennium Development Goals PPP conversion factor of $1.71)^{1}$.

\section{Inequality decomposition}

The measure of inequality used in the study is the Gini coefficient, which is additively decomposable by income sources or factor components (RAO, 1969): total inequality is the sum of the concentration coefficient of each factor, weighted by the share of this factor in total income.

The concentration coefficient ranges from -1 to +1 , attaining its minimum value when all income from source $k$ flows to the poorest individual in the overall distribution of income, and its maximum when flowing to the richest individual. However, when a factor component has both positive and negative values, there is a possibility that both its Gini and concentration coefficient might fall outside the $(0,1)$ and $(-1,1)$ ranges, respectively (CHEN, TSAUR AND RHAI, 1982; PYATT, CHEN and FEI, 1980; RAO, 1969). This is of concern as, for instance, both the public-private wage gap and the net State-related income components are expected to have both positive and negative values.

There are three alternatives for dealing with this situation. The first option is to adjust the scale of the Gini. The downside to this approach is that it creates the

1 See: <http://unstats.un.org/unsd/mdg/SeriesDetail.aspx?srid=699>. 
impression of an artificial reduction of the measured levels of inequality. The second option is to divide the factor component with positive and negative values in the two sub-factors, one with only positive values and the other with only negative ones. The third option is not to make any adjustments and accept concentration coefficients outside the conventional range.

Because our main objective is to estimate the relative contribution of income factor components to total inequality, we opted for the last two options, that is, to disaggregate all factors with positive and negative values into sub-factors with strictly non-positive and non-negative values, while also accepting an unconventional range for the original factor. By doing so, we did not compromise the comparability of our results with other studies.

The factor decomposition of the Gini coefficient allows us to calculate the income elasticity, or marginal effect on the contribution of each factor, to total inequality (LERMAN and YITZHAKI, 1985; STARK, TAYLOR and YITZHAKI, 1986). This elasticity indicates how a change in the share of a factor would affect total inequality. An income factor is "progressive" if it is less unequally distributed than total income; conversely, it is "regressive" if it is more unequally distributed. If a factor component of income is regressive, then its relative contribution to total inequality is higher than its income share and its marginal effect is inequalityincreasing.

In order to carry out the decomposition of the Gini coefficient, we began by dividing the disposable household income into three major groups: income flows from the State, to the State, and from the Private Sector. We then further subdivided the first two groups, as explained below. Incomes from the Private Sector were disaggregated solely into labor earnings and other incomes. The latter comprises a heterogeneous composition of income sources, such as capital and property, alimony, private pension plans, scholarships, and so on.

\section{Income flows from the State}

\section{Public servants' earnings}

Because of market segmentation, we treat the earnings of public servants as the sum of two components: their (counterfactual) private sector market 
earnings and the public-private wage differential. There are at least two possible explanations for this division and they can both be important determinants of the wage differences between the public and the private sectors. First, the wage setting mechanisms in the two sectors are different, with public sector wage values being highly influenced by political factors. Second, the characteristics of the public sector workers may also be different. To estimate these counterfactual wages, we resorted to the decomposition proposed by Juhn, Murphy, and Pierce (JMP), which allowed us to isolate the differential effects of coefficients (prices), observed characteristics (quantities) and residual effects using linear regressions (JUHN, MURPHY and PIERCE, 1993). First, we estimated a wage equation for the reference group, the public sector workers, and an equation for the equivalent group, the private sector workers. Then, we applied the regression parameters and the distribution of residuals from the equivalent group to the reference group to estimate the counterfactual wage of public sector workers. By subtracting the two, we obtained the wage differential.

We defined the group of comparable private sectors workers as all nondomestic formal private sector employees, which were identified as those individuals with private sector jobs who reported Social Security contributions and whose earnings were equal to the minimum wage or higher.

As the assumption that workers are randomly assigned between sectors is obviously not true, we tested three different specifications of our model. First, we estimated the wage equations without any sort of correction for selection bias. Then, we tested two different selection models and subsequently added the relevant Inverse Mills Ratios (IMRs) to the wage equations: a public or formal private job probit (only for those working in the formal sector, public or otherwise); and a work/does not work probit. The additional identification variables were the relationship to the household head (four dummies; household head as reference), the presence of children in the household (dummies for children aged 0-6 and 7-15 years) and the presence of other public sector workers in the household.

The wage equations themselves used the standard set of independent variables: education (six dummy variables; four years of schooling or less as reference); age and age squared; duration of job tenure (two dummies; workers 
with less than a month on the job as reference); gender (one dummy variable for men); race (one dummy variable for whites and Asians); states (26 dummy variables; state of Rondônia as reference); urbanization status (one dummy variable for urban areas). The dependent variable was the log of the monthly earnings.

All three models yielded similar results. The public-private wage gap was approximately $24 \%$, that is, public servants earned on average $22 \%$ more than they would earn in the private sector, given their observable characteristics. Moreover, the Gini coefficient for counterfactual wages was between 15\% and $20 \%$ lower than the Gini for observed wages. Therefore, we judged the results to be sufficiently robust to changes in definitions and model specifications such to allow us to present only the results based on the model with no correction for selection bias.

One could argue that our model might still be biased, insofar as our set of independent variables and selection equations do not fully take into account a host of potential selection biases. There is no conclusive evidence either way. However, it is worth mentioning that our results are consistent with estimates based on different methods and data sets (BARBOSA, 2012; BARBOSA and SOUZA, 2012; VAZ and HOFFMANN, 2007).

\section{Social security pensions}

Brazilian public pensions are organized as a mandatory pay-as-you-go system and divided into two subsystems, or regimes: one for private sector workers and another for public sector workers. The private sector regime has a legal cap that limits the values of its pensions and the employees' Social Security contributions. This cap does not apply to the public sector pensions. Recent reforms have changed this, but they will take a long time to take effect, as the cap will be imposed only upon workers who joined the public sector after the reforms were signed into law. Even then, there will remain some important differences, as these reforms also created partly subsidized voluntary retirement funds to supplement public servants' pensions.

The second important difference relates to the role of the minimum wage, which is the legal basis for all Social Security benefits. While there are very few 
minimum wage recipients among retired public servants, approximately twothirds of all private sector pensions are at the minimum wage level ( $R \$ 465$ as of June 2009, or PPP\$272)). This means that the annual adjustments to the minimum wage have a huge impact on these private sector pensions, which become independent from their recipients' contributions. The third difference relates to the rules governing the adjustment of the benefits. For private sector workers, benefits either follow the minimum wage or are otherwise adjusted annually for inflation. Former public servants, however, enjoy earnings parity with current public servants, as their pension benefits automatically reflect any rise in the wages of current servants. While the reforms approved in 2003 and 2005 have eliminated this privilege, all public servants who joined the public sector before 2003 are eligible for pensions with earnings parity.

In summary, it is hardly controversial to posit that the rules governing public servants' pensions are more generous than those rules for private sector pensions. Both regimes run significant annual deficits-between $1 \%$ (private sector regime) and 2\% (public servants' regime) of GDP - and thus have to be partially subsidized by the State.

For the Gini decomposition, the public pension incomes were first divided into pensions for private sector workers and for public sector workers. This latter group was further subdivided into pensions equal to or below the cap, and pensions above the cap. Finally, pensions above the cap were split into two income components, one equal to the cap and the other representing the "surplus" enjoyed by some retired public servants, as they are not subjected to the pension cap applied to private sector workers.

\section{Social assistance transfers}

Social Assistance encompasses all non-contributory cash benefits, except for the Rural Pensions, which are part of the Social Security pensions. Two major federal programs are responsible for almost all transfers: the Benefício de Prestação Continuada (BPC) and the Bolsa Família. The BPC is an unconditional monthly benefit equal to one minimum wage targeted to poor people aged 65 or older or with severe disabilities. 


\section{Unemployment benefits}

There are two major types of unemployment benefits available mostly for formal wage workers in the private sector. The first is the Fundo de Garantia por Tempo de Serviço (FGTS), a mandatory individual savings account. Workers can withdraw their savings upon dismissal or under certain other conditions. The second type of benefit is the Seguro Desemprego, a traditional temporary unemployment insurance transfer paid to formal workers upon their dismissal. Unlike the FGTS, the Seguro Desemprego has both a floor (the minimum wage) and a cap (usually between $160 \%$ and $180 \%$ of the minimum wage). Both the FGTS and the traditional unemployment insurance were classified as "unemployment benefits" and computed as they are in the database.

\section{Direct income flows to the State}

Direct income flows to the State comprise direct taxes and employees' contributions to Social Security. Taxes include all direct taxes registered by our survey, with income, vehicle, and land taxes being the most important ones by far.

Social Security contributions were divided into two income factor components, contributions to the private sector regimes, and those to the public sector regimes. Most active public and private sector workers' pay a flat rate of approximately $11 \%$ of their wages (in the latter case, only up to the value of the wages below the pension cap). Public sector pensioners-whose Social Security contributions had to be imputed - pay the same rate on the portion of their pensions that exceeds the cap.

Public sector workers' contributions were divided into contributions up to the cap, and those above the cap. Finally, this last factor was split into the share of contributions equaling the cap, and the share exceeding the cap. Thus, whenever public sector workers earned twice as much as the benefit cap, their Social Security contributions were split evenly between the latter two components of total income. We did not take into account the employers' contributions to Social Security in either the public or the private sector.

\section{Results and discussion}

Descriptive statistics for the factor components of total income are shown in Table 01 . More than $40 \%$ of the household disposable income flows from State 
transfers and payments, which are delivered to families encompassing almost twothirds of the total population. Once we subtract the taxes and contributions, the net income flow from the State falls to $30 \%$ of the disposable income. Only $10 \%$ of the population lives in households that neither pay nor receive any money to/from the State.

Table 01. Income components' descriptive statistics, Brazil - 2008-2009

\begin{tabular}{|c|c|c|c|c|}
\hline Factor Components of Total Income & $\begin{array}{l}\text { Monthly per } \\
\text { capita income } \\
2009 \text { PPP } \\
\text { Dollars }\end{array}$ & $\%$ of DPI & $\begin{array}{l}\% \text { of pop } \\
\text { affected }\end{array}$ & $\begin{array}{c}\text { Conditional } \\
\text { per capita } \\
\text { income } \\
2009 \text { PPP } \\
\text { Dollars }\end{array}$ \\
\hline 1 Public servants' earnings & 66 & 18.3 & 15.5 & 427 \\
\hline 1.1 Simulated & 54 & 15.0 & 15.5 & 349 \\
\hline 1.2 Public-private wage gap & 12 & 3.3 & 15.5 & 78 \\
\hline 1.2.1. Positive & 14 & 4.0 & 8.2 & 174 \\
\hline 1.2.2. Negative & -02 & -0.6 & 7.3 & -30 \\
\hline 2 Unemployment benefits & 05 & 1.3 & 16.3 & 29 \\
\hline 3 Social Security pensions & 74 & 20.4 & 30.9 & 239 \\
\hline 3.1 Private sector & 51 & 14.1 & 28.0 & 182 \\
\hline 3.2 Public sector & 23 & 6.3 & 4.3 & 534 \\
\hline $3.2 .1<=$ pension cap & 09 & 2.4 & 3.5 & 241 \\
\hline $3.2 .2>$ pension cap & 14 & 4.0 & 1.0 & 1,448 \\
\hline 3.2.2.1 Share = cap & 06 & 1.7 & 1.0 & 638 \\
\hline 3.2.2.2 Share $>$ cap & 08 & 2.2 & 1.0 & 810 \\
\hline 4 Social assistance transfers & 04 & 1.0 & 21.2 & 17 \\
\hline 5 Private Sector labor earnings & 227 & 62.8 & 86.1 & 264 \\
\hline 6 Other Private Sector incomes & 27 & 7.6 & 24.6 & 112 \\
\hline 7 Taxes & -41 & -11.4 & 72.2 & -57 \\
\hline 7.1 Direct taxes & -27 & -7.6 & 60.5 & -45 \\
\hline 7.2 Social Security contributions & -14 & -3.8 & 50.9 & -27 \\
\hline 7.2.1 Private sector & -08 & -2.2 & 41.4 & -19 \\
\hline 7.2.2 Public sector & -06 & -1.6 & 14.8 & -39 \\
\hline 7.2.2.1<= pension cap & -02 & -0.7 & 12.5 & -20 \\
\hline 7.2.2.2 > pension cap & -03 & -0.9 & 7.5 & -44 \\
\hline 7.2.2.2.1 Share = cap & -01 & -0.3 & 2.1 & -55 \\
\hline 7.2.2.2.2 Share $>$ cap & -02 & -0.6 & 7.5 & -28 \\
\hline 8 Disposable per capita income & 362 & 100.0 & 99.9 & 362 \\
\hline 8.1 State, gross & 149 & 41.0 & 65.1 & 228 \\
\hline 8.2 State, net & 107 & 29.7 & 89.9 & 119 \\
\hline
\end{tabular}

Source: POF 2008-2009.

Note: The columns refer to average monthly household per capita income, percentage of household disposable per capita income, percentage of the population in affected households and average monthly household per capita income, conditional on being affected. Public servants' earnings is the simulated counterfactual (1.1) plus the publicprivate wage gap (1.2). The gap is positive when observed earnings are higher than the ones simulated by the JMP decomposition and negative otherwise. Social Security pensions is the sum of private and public sector's pensions $(3.1+3.2)$. The public sector's pensions is the sum of pensions below or equal to the cap (3.2.1) and pensions above the cap (3.2.2). The latter were divided into two components, the share up to the value of the private sector cap and the share above it $(3.2 .2=3.2 .2 .1+3.2 .2 .2)$. The same applies to the taxes, which are the direct taxes plus the Social Security contributions $(7.1+7.2=7.1+7.2 .1+$ 7.2.2.1 + 7.2.2.2.1 + 7.2.2.2.2). Disposable per capita income is the sum of all positive incomes $(1+2+3+4+5+6)$ and the negative incomes (7). The gross State transfers are the public servants' earnings (1) plus unemployment benefits (2) plus Social Security pensions (3) plus social assistance transfers (4). The net State incomes flows are the gross transfers plus the negative incomes (7). 
Public servants' earnings and Social Security pensions dwarf other Staterelated income components. Consequently, the overall direct contribution of the State to income inequality is largely determined by their distribution, which is in turn, heavily influenced by the public-private wage gap and the differentiation of pension rules for workers in each sector. Wage differentials and pension advantages for public sector workers amount to $6 \%$ of the disposable per capita income and are more than double the sum of unemployment benefits and social assistance transfers, providing higher benefits to a much smaller clientele.

Results of the factor decomposition of the Gini coefficient of household disposable per capita income in Brazil are presented in Table 02. The first column shows the concentration coefficient of each income component, while the second shows the absolute contribution of the factor to the Gini (the product of the concentration coefficients by the income shares shown in Table 01), which is transformed into a relative contribution in the third column. The last column shows the income elasticity of the contribution (or marginal effect) of the factor to inequality, indicating how a percentage change in each factor would affect total inequality.

Direct income flows from the State make an important contribution to income inequality in Brazil. Approximately one third of total income inequality can be directly attributed to transfers made from the State to individuals, even after discounting the equalizing effect of direct taxes and contributions. Proportionally, the State contributes more to inequality than the private sector. Most income inequality appears in the private sector, as it accounts for $70 \%$ of the disposable income, more than twice the share of net State transfers. However, incomes in the private sector are less concentrated and this leads to a contribution to inequality of $68 \%$. The State, responsible for $30 \%$ of incomes, contributes to $32 \%$ of inequality. The income elasticity of contribution of the State to inequality is slightly positive; a proportional 1\% increase in net State transfers would increase the Gini coefficient by $0.022 \%$. The role of the State in inequality deserves further analysis, particularly regarding wages and pensions. 
Table 02.Income factor decomposition of inequality in household disposable per capita income - Brazil - 2008-2009

\begin{tabular}{|c|c|c|c|c|}
\hline $\begin{array}{l}\text { Factor Components of Total } \\
\text { Income }\end{array}$ & $\begin{array}{r}\text { Concentration } \\
\text { Coefficient }\end{array}$ & $\begin{array}{r}\text { Contribution } \\
\text { Gini }\end{array}$ & $\begin{array}{l}\% \text { of } \\
\text { Gini }\end{array}$ & Elasticity \\
\hline 1 Public servants' earnings & 0.742 & 0.136 & 24.2 & 0.059 \\
\hline 1.1 Simulated & 0.702 & 0.102 & 18.7 & 0.038 \\
\hline 1.2 Public-private wage gap & 0.922 & 0.031 & 5.5 & 0.021 \\
\hline 1.2.1. Positive & 0.853 & 0.034 & 6.0 & 0.021 \\
\hline 1.2.2. Negative & 0.483 & -0.003 & -0.5 & 0.001 \\
\hline 2 Unemployment benefits & 0.591 & 0.008 & 1.4 & 0.001 \\
\hline 3 Social Security pensions & 0.582 & 0.119 & 21.1 & 0.008 \\
\hline 3.1 Private sector & 0.474 & 0.067 & 11.9 & -0.022 \\
\hline 3.2 Public sector & 0.824 & 0.052 & 9.3 & 0.030 \\
\hline $3.2 .1<=$ pension cap & 0.624 & 0.015 & 2.6 & 0.003 \\
\hline $3.2 .2>$ pension cap & 0.943 & 0.037 & 6.6 & 0.027 \\
\hline 3.2.2.1 Share = cap & 0.916 & 0.016 & 2.8 & 0.011 \\
\hline 3.2.2.2 Share $>$ cap & 0.964 & 0.021 & 3.8 & 0.016 \\
\hline 4 Social assistance transfers & -0.348 & -0.003 & -0.6 & -0.016 \\
\hline 5 Other labor earnings & 0.522 & 0.328 & 58.4 & -0.044 \\
\hline 6 Other incomes & 0.729 & 0.055 & 9.8 & 0.023 \\
\hline 7 Taxes & 0.707 & -0.081 & -14.3 & -0.030 \\
\hline 7.1 Direct taxes & 0.744 & -0.056 & -10.0 & -0.025 \\
\hline 7.2 Social Security contributions & 0.635 & -0.024 & -4.3 & -0.005 \\
\hline 7.2.1 Private sector & 0.542 & -0.012 & -2.1 & 0.001 \\
\hline 7.2.2 Public sector & 0.765 & -0.012 & -2.2 & -0.006 \\
\hline 7.2.2.1<= pension cap & 0.571 & -0.004 & -0.7 & 0.000 \\
\hline 7.2.2.2 > pension cap & 0.912 & -0.008 & -1.5 & -0.006 \\
\hline 7.2.2.2.1 Share = cap & 0.883 & -0.003 & -0.5 & -0.002 \\
\hline 7.2.2.2.2 Share $>$ cap & 0.928 & -0.005 & -1.0 & -0.004 \\
\hline 8 Disposable per capita income & & 0.561 & 100 & 0.000 \\
\hline 8.1 State, gross & 0.632 & 0.259 & 46.1 & 0.051 \\
\hline 8.2 State, net & 0.602 & 0.178 & 31.8 & 0.022 \\
\hline
\end{tabular}

Source: POF 2008-2009.

Note: Public servants' earnings is the simulated counterfactual (1.1) plus the public-private wage gap (1.2). The gap is positive when observed earnings are higher than the ones simulated by the JMP decomposition and negative otherwise. Social Security pensions is the sum of private and public sector's pensions $(3.1+3.2)$. The public sector's pensions is the sum of pensions below or equal to the cap (3.2.1) and pensions above the cap (3.2.2). The latter were divided into two components, the share up to the value of the private sector cap and the share above it $(3.2 .2=3.2 .2 .1+3.2 .2 .2)$. The same applies to the taxes, which are the direct taxes plus the Social Security contributions $(7.1+7.2=7.1+7.2 .1+7.2 .2 .1+$ 7.2.2.2.1 + 7.2.2.2.2). Disposable per capita income is the sum of all positive incomes $(1+2$ $+3+4+5+6$ ) and the negative incomes (7). The gross State transfers are the public servants' earnings (1) plus unemployment benefits (2) plus Social Security pensions (3) plus social assistance transfers (4). The net State incomes flows are the gross transfers plus the negative incomes (7).

\section{Public sector wages}

In several developed countries, public work contributes to reduced inequality (BLAU AND KAHN, 1996; GUSTAFSSON and JOHANSSON, 1999; MILANOVIC, 1994). This is not the case in Brazil. Remuneration for public sector workers is more concentrated and has a higher marginal effect on income inequality than remuneration for private sector workers. Public sector wages have an income share of $19 \%$, but contribute to $24 \%$ of income inequality, whereas 
private sector earnings contribute to $58 \%$ of total income inequality, despite amounting to $63 \%$ of all incomes.

There are two effects behind the regressiveness of public sector wages: a composition effect and a segmentation (price) effect. The composition effect results from the fact that public sector workers are, on average, better educated than the rest of the labor force. As such, these workers would occupy the higher strata of the income distribution even if the wage structures in the public and private sector were the same (BENDER and FERNANDES, 2009; FOGUEL et al., 2000; VAZ and HOFFMANN, 2007).

The dividing effect, in turn, is associated with the particularities of the public sector in determining wages, not only because the objectives of this sector are different from those of the private sector, but also because the collective organization of workers in this segment of the labor market is very specific. While wage schedules in private enterprises are usually guided by profit-maximization, public administrators are influenced by political goals. They may use the State wage policy as a means to increase their popularity and gain support from the bureaucracy to pursue those goals, which easily results in higher wages for government employees (GREGORY and BORLAND, 1999). Moreover, if unionization is marked by corporatism, powerful unions operating in the wellorganized and legally protected segment of the labor market can, in fact, increase total inequality.

There is much evidence of composition and segmentation effects acting to create a public-private wage differential in Brazil. Most of the differences in averages are due to composition effects, yet there is a segmentation effect acting to render salaries in the public sector higher than those paid in the private sector for equivalent workers in equivalent jobs (BARBOSA, 2012; BARBOSA and SOUZA, 2012; BELLUZZO, ANUATTI-NETO and PAZELLO, 2005; BENDER and FERNANDES, 2009; BRAGA, 2007; DARÉ, 2011; DARÉ and HOFFMANN, 2012; FOGUEL et al., 2000; PANIZZA and QIANG, 2005; SOUZA and MEDEIROS, 2013; VAZ and HOFFMANN, 2007; VERGARA, 1991; VERGARA and SILVA WILTGEN, 1995).

The factor decomposition in Table 02 illustrates the fact that the State hires workers with better qualifications than the labor force average-the composition effect-, is more relevant for household disposable per capita income 
inequality than the consequences of segmentation on the prices of labor. Approximately $19 \%$ of total income inequality is related to the particular composition of the public sector, whereas $6 \%$ refers to the wage differential favoring workers in the public sector. Of course, it is difficult to determine whether this differential results from pure segmentation of the job market into public and private sectors, or from other characteristics of the workers in the two sectors. Still, the importance of this wage differential to inequality should not be overlooked. No matter what the causal effects behind the differential are, it is extremely concentrated and its regressive impact on the Gini coefficient is sufficient to offset over half of the progressive impact of the income tax.

The public sector has an intra-sector earnings concentration higher than that of its private counterpart. Its concentration coefficient is 0.742 , whereas that of the private sector is 0.522 . This, combined with a highly concentrated wage differential that on average favors the public sector, results in a disproportional contribution of the latter to inequality, $24.2 \%$ of the Gini coefficient, when compared to that of the private sector (58.4\%); which encompasses a more than five times larger share of the labor force. In other words, the considerable importance of public sector earnings to inequality results from the interaction of high concentration within this sector and inequalities between the sectors.

\section{Social security pensions}

The outcome of the combination of redistributive and regressive benefits characterizing public pensions in Brazil is far from egalitarian, contributing to $21 \%$ of total income inequality in the country. High levels of regressiveness are characteristic of the pension system of several Latin American countries (ARZA, 2008; ESQUIVEL, 2011; FERREIRA, 2006; HOFFMANN, 2003a, 2003b; LAVADO, 2007; MEDEIROS and SOUZA, 2013, 2014; RANGEL, 2011; RANGEL, VAZ and FERREIRA, 2009; SILVEIRA, 2008, 2010; SOARES et al., 2009). However, the disaggregation between public pensions for workers in the private sector and for those in the public sector shows that the system is heterogeneous. With regard to public pensions, the country aligns with other countries with a corporatist bias in the origin of their social policies (PALME, 2006; PEDRAZA, LLORENTE and RIVAS, 
2009; WANG, CAMINADA and GOUDSWAARD, 2012), but with a much worse distribution of benefits from these policies.

In practice, the Brazilian Social Security system is stratified into at least three tiers. At the bottom, there are the subsidized minimum wage pensions, paid either to former rural or urban workers who were on the fringes of the formal market. In the middle, there are the other private sector pensioners and the public servants whose pensions are lower than or equal to the private sector pension cap. At the top, there are the few public sector retirees whose pensions exceed the cap. Public pensions are the most important item of social spending in Brazil.

Pensions for workers in the public sector are very concentrated-they have a coefficient of concentration of $0.824,47 \%$ higher than the already excessive concentration of incomes in Brazil of 0.561 . Although only $4 \%$ of the population lives in families receiving public sector pensions, they amount to $6 \%$ of all incomes and respond to $9 \%$ of the Gini coefficient. There is no other source of income with such a high proportional contribution to inequality.

Pensions above the cap have the highest concentration among all income components; the share above the cap of these pensions alone amounts to $2 \%$ of all incomes and $4 \%$ of total inequality. Progressive contributions to the system made by active workers could counteract the effects of the concentration of pensions on inequality, but they do not. Social Security contributions are generally progressive but they represent only a small fraction of total income, so their impact upon inequality is limited: the share of public servants' pensions above the cap offsets almost all of their equalizing effects.

Public pensions for the workers in the private sector are also concentrated, but given the level of inequality in Brazil, they end up being slightly progressive. While public pensions for private sector workers represent $14 \%$ of all family incomes, they contribute to $12 \%$ of total inequality. This results from a combination of three factor components: first, rural pensions provide income for families that otherwise would be very poor; second, the minimum wage floor pushes up those who were low income workers and made small contributions; third, a cap ensures that pensions will not reach very high values.

Behind the concentration of pensions is the momentum created by a once strongly corporatist welfare state. Even though recent reforms made important 
steps toward convergence, the more egalitarian rules apply only to new hires in the public sector. Unless an equalizing mechanism is adopted, the inequality that is already perpetuated by a contributory system will be sustained until the demographics of the pension system change completely.

\section{Other direct income flows to and from the state and private sector incomes}

Not all State monetary transfers are inequality-increasing. Social assistance - basically targeted cash transfers of anti-poverty programs - is highly progressive and contributes to reverse inequality (BARROS et al., 2007; HOFFMANN, 2009; MEDEIROS and SOUZA, 2013; ROCHA, 2008; SOARES et al., 2009). However, as they represent a minor share of the income received by families $(1 \%)$, their contribution to inequality is minimal $(-1 \%)$. Their impact is completely offset by unemployment insurance benefits and individual accounts drawdowns, which amount to a minor share of total income (1\%). The celebrated Brazilian two-pillared anti-poverty system, based on the Bolsa Família and the $\mathrm{BPC}$, amounts to a small droplet of redistribution in a large pool of State regressive actions.

Some studies on OECD countries argue that universalist policies legitimize more social spending, and therefore countries with corporatist models of a welfare state are more capable of reducing inequality than those which targeted social assistance (KORPI and PALME, 1998; SMEEDING, 2005). A recent study of OECD countries in 2004 estimates that welfare states, on average, reduce inequality by 35\% (WANG, CAMINADA and GOUDSWAARD, 2012). This estimate, however, should be taken with caution, as it is based on a sequential accounting decomposition, that is, the simple recalculation of inequality after the counterfactual suppression of a source of incomes. As Hoffmann (2013) shows, this decomposition may imply reordering within the distribution of incomes that would result in a measurement of the contribution to inequality lacking substantive meaning. When the same data are analyzed with the factor decomposition methodology, the conclusion is that welfare benefits play a negligible role in reducing inequality (FUEST, NIEHUES and PEICHL, 2010; LEFEBVRE, 2007; WANG, CAMINADA and GOUDSWAARD, 2012). 
There is no evidence that more social spending reduces inequality in Brazil. Expenditures for regressive pensions already amount to a fifth of all family income-but progressive targeted social assistance has not increased accordingly and is still twenty times lower than that of expenditures on pensions.

In the case of Brazil, it makes more sense to argue that workers in the more developed sectors of the economy form an organized interest group much more powerful than the unorganized mass formed by potential beneficiaries of social assistance. Historically, elites in all Latin American countries used social security to co-opt the military, public servants and some unions for their projects and to attract support to generate political stability. The result is a stratified social protection system where, on one extreme, a large number of poor families can only count on meager social assistance benefits or minimum wage pensions upon retirement, and on the other extreme, a restricted number of well-paid public servants are afforded an outstanding income protection system.

It seems that what matters to inequality in a late development welfare state is not so much the design of the policies (targeted versus universal) but rather the unbalanced distribution of power between oligarchies and the rest of the population that precedes that design and determines the level of transfers to different social groups, irrespective of the aggregate level of spending.

Taxes and contributions to pensions could reverse the regressive effect of social security, as they often do in OECD countries (ATKINSON, 2003; GOTTSCHALK and SMEEDING, 1997). Indeed, direct taxation is very progressive and contributes to reducing the Gini by $10 \%$. Yet, direct taxes account for barely $20 \%$ of the total tax revenue in Brazil. As a consequence, most of the tax load is levied on production and consumption, and therefore paid more or less equally by the entire population (PINTOS-PAYERAS, 2010; SILVEIRA, 2008, 2010). Thus, the problem resides not so much in the level of taxation, but in its composition. Our study does not include individual data regarding indirect taxes; however, it is reasonable to infer that if all taxes had the distributional profile of the income taxes, then inequality in the country would be much lower.

The "Other incomes" received from the private sector include real estate rents and interests, and therefore tend to be concentrated. Nevertheless, they contribute to only $10 \%$ of total inequality. We believe this contribution is not 
larger because a reasonable share of capital incomes are directly paid to companies and financial funds-not individuals-and because the incomes directly received by families are underreported, as studies using tax data suggest (MEDEIROS, SOUZA and CASTRO, 2015a, 2015b).

\section{Conclusions}

By means of its direct monetary income flows, the State contributes a large share of the high level of income inequality in Brazil; proportionally, it contributes more to inequality than the private sector. Approximately one-third of all inequality in the country is related to direct transfers, payments, and taxes that flow between the State and families. The two major types of State income flows affecting inequality are wages and pensions. The other two-thirds of total inequality are related to transfers from the private sector, which are primarily some form of remuneration for work.

We did not consider the effects of indirect flows of income, such as subsidies to companies in the form of cash or special credit, or indirect taxes. As those subsidies tend to benefit stakeholders of larger companies and those in the upper tiers of the income distribution, computing them would probably make the State's contribution to inequality even higher. By their turn, indirect taxation is known to be slightly regressive; therefore considering this taxation would not change our conclusions.

Contrary to what has been found in OECD countries, public sector wages in Brazil are more concentrated than those of the private sector, resulting in a disproportionate contribution of public work to inequality: while public sector wages amount to little less than a fifth of all incomes, they contribute to almost one quarter of inequality. There are two effects making these wages regressive. The first one is a composition effect, that is, workers in the public sector are better educated than the labor force average, and thus receive higher wages. The second is a segmentation effect, possibly caused by a combination of a particular wage structure and a selection of better qualified workers through public competition.

We found that, for the most part, public sector workers are better remunerated than their private sector counterparts. This wage differential contributes to approximately $6 \%$ of inequality. It is a small contribution, but its 
importance in the long term should not be underestimated as, in the future, it will be replicated by the pension system. Neither should its relevance in terms of an income flow from the State be neglected, as the effect of this wage differential on inequality is sufficient to offset half of the progressive effect of direct taxes. Approximately $18 \%$ of total inequality is related to the fact that workers in the public sector possess characteristics that the labor market recognizes as important, and thus remunerates them better.

Pensions are the second major type of State transfer in Brazil. They amount to approximately $20 \%$ of all incomes. As a whole, the pension system combines redistributive and regressive benefits but its outcome is slightly inequality-increasing. Pensions contribute to approximately one fifth of all inequality. This occurs because the system is contributory-therefore it tends toward the replication of previous inequalities-and is divided into two subsystems operating with distinctly different rules. The subsystem for private sector workers has a floor and a cap, which restricts the range within which the value of pensions can vary. The subsystem for public sector workers, in turn, also has a floor but not a cap, therefore allowing much more variation.

The characteristics and composition of workers in the public sector result in higher wages and, consequently, higher Social Security contributions and higher pensions. This, combined with the absence of a cap, makes the public workers pension subsystem regressive. The share of pensions exceeding the cap is so regressive that it alone offsets the sum of the progressive effects of all direct contributions to pensions, both from private and public sector workers. It appears that this negative effect on inequality will persist for decades, as the convergence of the two sectors will happen only in the long term since the equalization of rules applies only to new hires of workers in the public sector.

In summary, there is evidence that the State operates its wage and social policies in a three-tiered fashion: on the first tier, there is an elite of highly qualified public sector workers with high wages and pensions, which concentrates incomes; on the second tier, the State provides intermediate pension benefits and unemployment insurance only to formal workers in the private sector-these benefits are still concentrated, but progressive; lastly, for the third tier the State has highly egalitarian policies, such as exemption from income taxes and basic 
income policies for the low income masses in the informal sector, but the share of these measures within total income is small. The final balance is that the direct flows of income to and from the State contribute to increased inequality. Egalitarian transfers such as social assistance and taxes are more than offset by regressive transfers such as public wages and pensions.

Revised by Cabo Verde Submitted in September 2014

Accepted in February 2015

\section{References}

AFONSO, L. E and FERNANDES, R. (2005), Uma estimativa dos aspectos distributivos da Previdência Social no Brasil. Revista Brasileira de Economia. Vol. 59, № 03, pp. 295-334.

ARZA, Camila (2008), Pension reform in Latin America: distributional principles, inequalities and alternative policy options. Journal of Latin American Studies. Vol. 40, № 01, pp. 01-28.

ATKINSON, Anthony B. (2003), Income inequality in OECD countries: data and explanations. CESifo Economic Studies. Vol. 49, № 04, pp. 479-513.

BARBOSA, Ana Luiza Neves de Holanda (2012), Ensaios sobre diferencial de salários e estimação de demanda no Brasil. Thesis. Rio De Janeiro: Fundação Getúlio Vargas. http://bibliotecadigital.fgv.br/dspace/handle/10438/9365.

BARBOSA, Ana Luiza Neves de Holanda and SOUZA, Pedro Herculano Guimarães Ferreira (2012), Diferencial salarial público-privado e desigualdade dos rendimentos do trabalho no Brasil. Boletim Mercado de Trabalho - Ipea. Vol. 53, pp. 29-36.

BARROS, Ricardo Paes de; CARVALHO, Mirela; FRANCO, Samuel and MENDONÇA, Rosane (2007), O papel das transferências públicas na queda recente da desigualdade de renda brasileira. In: Desigualdade de renda no Brasil: uma análise da queda recente. Edited by: BARROS, Ricardo Paes de; FOGUEL, Miguel Nathan and ULYSSEA, Gabriel. 1st ed.. Vol. 02, № 16, pp. 41-86. Brasília: Ipea.

BELlUZZO, W.; ANUATTI-NETO, F. and PAZELLO, E. T. (2005), Distribuição de salários e o diferencial público-privado no Brasil. Revista Brasileira de Economia. Vol. 59, № 04, pp. 511-533.

BENDER, S. and FERNANDES, R. (2009), Gastos públicos com pessoal: uma análise de emprego e salário no setor público brasileiro nos anos 90. Revista EconomiA. Vol. 10, № 01, pp. 19-47. 
BLAU, Francine D. and KAHN, Lawrence M. (1996), International differences in male wage inequality: institutions versus market forces. Working Paper 4678. NBER Working Paper. Cambridge, MA: National Bureau of Economic Research. http://www.nber.org/papers/w4678.

BRAGA, B. G. (2007), Capital humano e o diferencial de salários público-privado no Brasil. In: Anais Do XXXV Encontro Nacional de Economia [Proceedings of the 35th Brazilian Economics Meeting], pp. 01-15. ANPEC-Associação Nacional dos Centros de Pósgraduação em Economia [Brazilian Association of Graduate Programs in Economics].

CARVALHO, Diogo Baerlocher; SIQUEIRA, Rozane Bezerra de and NOGUEIRA, José Ricardo Bezerra (2013), Características distributivas e impacto de reformas tributárias sobre o bem-estar das famílias no Brasil. Revista Brasileira de Economia. Vol. 67, № 03, pp. 263-282.

CASTRO, Fábio Avila (2014), Imposto de renda da pessoa física: comparações internacionais, medidas de progressividade e redistribuição. Dissertação de Mestrado em Economia. Brasília: Universidade de Brasília.

CHECCHI, Daniele and GARCÍA-PEÑALOSA, Cecilia (2010), Labour market institutions and the personal distribution of income in the OECD. Economica. Vol. 77, № 307, pp. 413-450.

CHEN, Chau-Nan; TSAUR, Tien-Wang and RHAI, Tong-Shieng (1982), The Gini coefficient and negative income. Oxford Economic Papers. New Series. Vol. 34, № 03, pp. 473-478.

DARÉ, Eduardo Freguglia (2011), Desigualdade da distribuição da renda no Brasil: a contribuição dos rendimentos do funcionalismo público. Dissertação de Mestrado em Economia. Campinas: Universidade de Campinas.

DARÉ, Eduardo Freguglia and HOFFMANN, Rodolfo (2012), Desigualdade da distribuição de renda no Brasil: a contribuição dos rendimentos do funcionalismo público. Boletim Mercado de Trabalho - Ipea. Vol. 53, № 11.

ESQUIVEL, Gerardo (2011), The dynamics of income inequality in Mexico since NAFTA. Economía. Vol. 12, № 01, pp. 155-179.

FERREIRA, Carlos Roberto (2006), Aposentadorias e distribuição da renda no Brasil: uma nota sobre o período 1981 a 2001. Revista Brasileira de Economia. Vol. 60, № 03, pp. 247-260.

FOGUEL, Miguel N.; GILL, Indermit; , MENDONÇA, Rosane and BARROS, Ricardo Paes de (2000), The public-private wage gap in Brazil. Revista Brasileira de Economia. Vol. 54, December, pp. 433-472.

FUEST, Clemens; NIEHUES, Judith and PEICHL, Andreas (2010), The redistributive effects of tax benefit systems in the enlarged EU. Public Finance Review. Vol. 38, № 04, pp. 473-500. 
GOTTSCHALK, Peter and SMEEDING, Timothy M. (1997), Cross-national comparisons of earnings and income inequality. Journal of Economic Literature. Vol. 35, № 02, pp. 633-687.

GOUDSWAARD, Kees and CAMINADA, Koen (2010), The redistributive effect of public and private social programmes: A cross-country empirical analysis. International Social Security Review. Vol. 63, № 01, pp. 01-19.

GREGORY, R. G. and BORLAND, J. (1999), Recent developments in public sector labor markets. Handbook of Labor Economics. Vol. 03, № 03, pp. 3573-3630.

GUSTAFSSON, Björn and JOHANSSON, Mats (1999), In search of smoking guns: what makes income inequality vary over time in different countries? American Sociological Review. Vol. 64, № 04, pp. 585-605.

HIGGINS, Sean and PEREIRA, Claudiney (2013), The effects of Brazil's taxation and social spending on the distribution of household income. Public Finance Review. September.

HOFFMANN, Rodolfo (2003a) Aposentadorias e pensões e a desigualdade da distribuição da renda no Brasil. Econômica. Vol. 05, № 01, pp. 135-144.

HOFFMANN, Rodolfo (2003b) Inequality in Brazil: the contribution of pensions. Revista Brasileira de Economia. Vol. 57, № 04, pp. 755-773.

HOFFMANN, Rodolfo (2009), Desigualdade da distribuição da renda no Brasil: a contribuição de aposentadorias e pensões e de outras parcelas do rendimento domiciliar per capita. Economia E Sociedade. Vol. 18, № 01, pp. 213-231.

HOFFMANN, Rodolfo (2013), How to measure the progressivity of an income component. Applied Economics Letters. Vol. 20, № 04, pp. 328-331.

IMMERVOLL, Herwig; LEVY, Horacio; NOGUEIRA, José Ricardo; O'DONOGHUE, Cathal; SIQUEIRA, De and BEZERRA, Rozane (2006), The impact of Brazi's taxbenefit system on inequality and poverty. 2114. IZA. Discussion Papers. http://www.econstor.eu/handle/10419/33838.

JUHN, C.; MURPHY, K. M. and PIERCE, B. (1993), Wage inequality and the rise in returns to skill. Journal of Political Economy. Vol. 101, № 03, pp. 410-442.

KORPI, Walter and PALME, Joakim (1998), The paradox of redistribution and strategies of equality: welfare state institutions, inequality, and poverty in the western countries. American Sociological Review. Vol. 63, № 05, pp. 661-687.

LAVADO, Pablo (2007), Desigualdad en los programas sociales en el Perú. Diagnóstico y propuesta 34. Diagnóstico y Propuesta. Lima: CIES.

LEFEBVRE, M. (2007), The Redistributive effects of pension systems in Europe: a survey of evidence. Luxembourg Income Study Working Paper 457. Luxembourg Income Study Working Paper Series. Luxembourg: Luxembourg Income Study. 
LERMAN, Robert I. and YITZHAKI, Shlomo (1985), Income inequality effects by income source: a new approach and applications to the United States. The Review of Economics and Statistics. Vol. 67, № 01, pp. 151-156.

MAHLER, Vincent A. and JESUIT, David K. (2006) Fiscal redistribution in the developed countries: new insights from the Luxembourg income study. SocioEconomic Review. Vol. 04, № 03, pp. 483-511.

MEDEIROS, Marcelo and SOUZA, Pedro H. G. F. (2013), Estado e desigualdade de renda no Brasil: fluxos de rendimentos e estratificação social. Revista Brasileira de Ciências Sociais. Vol. 28, № 83, pp. 141-150.

MEDEIROS, Marcelo and SOUZA, Pedro H. G. F. (2014), Previdências dos trabalhadores dos setores público e privado e desigualdade no Brasil. Economia Aplicada. Vol. 18, № 04, pp. 603-623. doi:http://dx.doi.org/10.1590/1413-8050/ea344.

MEDEIROS, M., Souza, P. H. G. F. de and Castro, F. A. (2015a). The stability of income inequality in Brazil, 2006-2012: an estimate using income tax data and household surveys. Ciência \& Saúde Coletiva, 20(4), 971-986. http://doi.org/10.1590/1413-81232015204.00362014

MEDEIROS, M., Souza, P. H. G. F., \& Castro, F. A. (2015b). O Topo Da Distribuição De Renda No Brasil: Primeiras Estimativas Com Dados Tributários E Comparação Com Pesquisas Domiciliares, 2006-2012. Dados - Revista de Ciências Sociais, 1(58), 7-36. http://doi.org/http://dx.doi.org/10.1590/001152582015

MILANOVIC, Branko (1994), Determinants of cross-country income inequality: an "augmented" Kuznets' hypothesis. Policy Research Working Paper 1246. World Bank Policy Research Working Paper. Washington, D.C.: World Bank Publications.

MOSTAFA, Joana; SOUZA, Pedro H. G. F. and VAZ, Fabio Monteiro (2010), Efeitos econômicos do gasto social no Brasil. In: Perspectivas da política social no Brasil. Edited by CASTRO, Jorge Abrahão; FERREIRA, Helder Rogério Sant'Ana; , CAMPOS, André Gambier and RIBEIRO, José Aparecido Carlos. Brasília: Ipea. pp. 109-160.

PALME, Joakim (2006), Welfare states and inequality: institutional designs and distributive outcome. Research in Social Stratification and Mobility. Vol. 24, № 04, pp. 387-403.

PANIZZA, Ugo and QIANG, Christine Zhen-Wei (2005), Public-private wage differential and gender gap in Latin America: spoiled bureaucrats and exploited women? Journal of Socio-Economics. Vol. 34, № 06, pp. 810-833.

PEDRAZA, Pablo de; LLORENTE, Rafael Muñoz de Bustillo and RIVAS, Luis Alberto (2009), Ageing population and spanish pension system reforms: effects on average pensions and inequality among pensioners. Economical Analysis Working Papers. Vol. 08, № 07, pp. 01-24. 
PINTOS-PAYERAS, José Adrian (2008), A carga tributária no Brasil e sua distribuição. Tese de Doutorado em Economia Aplicada. Piracicaba: Escola Superior de Agricultura Luiz de Queiroz, Universidade de São Paulo.

PINTOS-PAYERAS, José Adrian (2010), Análise da progressividade da carga tributária sobre a população brasileira. Pesquisa E Planejamento Econômico. Vol. 40, № 02, pp. 153-186.

PYATT, Graham; CHEN, Chau-nan and FEI, John (1980), The distribution of income by factor components. The Quarterly Journal of Economics. Vol. 95, № 03, pp. 451-473.

RANGEL, L. (2011), Aspectos distributivos do regime de previdência dos servidores públicos. Texto Para Discussão. Ipea, 1617. Ipea.

RANGEL, L.; VAZ, F. and FERREIRA, J. (2009), Desigualdade na distribuição de renda: enfoque nas aposentadorias e pensões públicas. Informe de Previdência Social. Brasília: Ministério Da Previdência Social. Vol. 21, № 05.

RAO, V. M. (1969), Two decompositions of concentration ratio. Journal of the Royal Statistical Society. Series A (General). Vol. 132, № 03, pp. 418-425.

ROCHA, Sonia (2002), 0 impacto distributivo do Imposto de renda sobre a desigualdade de desigualdade de renda das famílias. Pesquisa E Planejamento Econômico. Vol. 32, № 01, pp. 73-105.

ROCHA, Sonia (2008), Transferências de renda federais: focalização e impactos sobre pobreza e desigualdade. Revista de Economia Contemporânea. Vol. 12, № 01, pp. 67-96.

SANTOS, Claudio Hamilton (2010), Um panorama das finanças públicas brasileiras de 1995 a 2009. In: Tributação e equidade no Brasil: um registro da reflexão do Ipea no Biênio 2008-2009. Edited by CASTRO, Jorge Abrahão; SANTOS, Claudio Hamilton and RIBEIRO, José Aparecido Carlos. Brasília: Ipea. pp. 19-67.

SILVEIRA, Fernando Gaiger (2008), Tributação, previdência e assistência sociais: impactos distributivos. Tese de Doutorado em Economia. Campinas: Universidade de Campinas.

SILVEIRA, Fernando Gaiger (2010), Tributação, previdência e assistência sociais: impactos distributivos. In: Tributação e equidade no Brasil: um registro da reflexão do Ipea no Biênio 2008-2009. Edited by CASTRO, Jorge Abrahão; SANTOS, Claudio Hamilton and RIBEIRO, José Aparecido Carlos. Brasília: Ipea. pp. 67-124.

SMEEDING, Timothy M. (2005), Public policy, economic inequality, and poverty: the United States in comparative perspective. Social Science Quarterly. Vol. 86, pp. 955-983.

SOARES, Sergei; OSORIO, Rafael Guerreiro; SOARES, Fabio Veras; MEDEIROS, Marcelo and ZEPEDA, Eduardo (2009), Conditional cash transfers in Brazil, 
Chile and Mexico: Impacts upon Inequality. Estudios Económicos. N. ex: 207224.

SOARES, Sergei; SILVEIRA, Fernando Gaiger; SANTOS, Claudio Hamilton; VAZ, Fábio Monteiro and SOUZA, André Luis (2010), O Potencial redistributivo do Imposto de renda - Pessoa Física (IRPF). In: Tributação e equidade no Brasil: um registro da reflexão do Ipea no Biênio 2008-2009. Edited by CASTRO, Jorge Abrahão; SANTOS, Claudio Hamilton and RIBEIRO, José Aparecido Carlos. Brasília: Ipea. pp. 213-255.

SOUZA, Pedro H. G. F. and MEDEIROS, Marcelo (2013), Diferencial salarial públicoprivado e desigualdade de renda per capita no Brasil. Estudos Econômicos (São Paulo). Vol. 43, № 01, pp. 05-28. doi:http://dx.doi.org/10.1590/S010141612013000100001.

STARK, Oded; TAYLOR, J. Edward and YITZHAKI, Shlomo (1986), Remittances and inequality. The Economic Journal. Vol. 96, № 383, pp. 722-740.

VAZ, D. V. and HOFFMANN, Rodolfo (2007), Remuneração nos serviços no Brasil: o contraste entre funcionários públicos e privados. Economia E Sociedade. Vol. 16, pp. 199-232.

VERGARA, D. H. (1991), Diferenciais de salários entre os setores público e privado da economia brasileira. Ensaios FEE. Vol. 12, № 01, pp. 73-85.

VERGARA, D. H. and WILTGEN, R. da Silva (1995), Os diferenciais de salários entre o setor público e o setor privado na RMPA. Indicadores Econômicos FEE. Vol. 23 , № 03 , pp. 255-270.

WANG, Chen; CAMINADA, Koen and GOUDSWAARD, Kees (2012), The redistributive effect of social transfer programmes and taxes: a decomposition across countries. International Social Security Review. Vol. 65, № 03, pp. 27-48. 